\title{
Using On-line Testing for Civil Engineering Studies
}

\author{
By Anita Meldrum*
}

\begin{abstract}
The use of online resources in the assessment of engineering modules is generally being encouraged in HE institutions. This paper reflects upon the experience of open book testing of first year engineering students in two elements in a continuously assessed two semester long module. This mode of assessment is more convenient for the large percentage of part time students on the programme, who only attend one day per week. A longitudinal study over a five year period shows that not all students like to be assessed in this way, even though evidence indicates improvement in pass rates over those achieved from more traditional modes of testing.
\end{abstract}

\section{Introduction}

In higher education, we are being encouraged towards greater use of online resources for teaching and assessment. This is particularly true for those students who study part time, as they are working in industry and only attend for one intense day per week. They have to fit personal study into the evenings and weekends, so that effective time management is crucial for them.

I decided to start with a first year module where the teaching is over 24 weeks/2 semesters and assessment is continuous. One test per semester is on line/open book and the other assessments are a report/essay and an exam style final test each semester. My expectations were that students would prefer this open book mode of assessment to more formal, exam style testing, marking and feedback and that it might be possible to enhance pass rates for the module by using online resources, under my previous personal assumption that most students are web savvy.

\section{Pedagogical Background}

The pedagogy to using technology for teaching and assessment has its roots in $20^{\text {th }}$ century behavioural and cognitive theories of education (Harasim 2012). Behaviourist theories from the early $20^{\text {th }}$ century (Thorndike 1905 , Skinner 1948) rely upon the observation of people's behaviours and how to change them and are based upon empirical, observable and measurable factors and responses to stimuli. In terms of teaching, this means that the teacher

*Senior Lecturer, Glasgow Caledonian University, UK. 
provided information, formulae, experiments or ideas - the stimuli and the learner reacted to them by accepting, or questioning if they did not understand the material provided. This is quite a quite a traditional way of teaching and is rigid, inflexible and does not help the teacher to know if the learner has understood; as understanding cannot be seen or measured and only by testing can the student 'be seen to have learned' (Harasim 2012). In engineering teaching, the model (Goodhew 2010) was to ensure that the design process (the formulae and calculations) was communicated and as long as the student could emulate it at exam time, they could pass the course.

Moving forward into the mid- $20^{\text {th }}$ century, cognitive theories emerged (Atkinson and Shiffrin 1968, Baddeley and Hitch 1974) These stressed the importance of the mind (the unseen) in learning and attempted to emulate its functions by providing artificial and intelligent tutoring mechanisms that mimic the mind's processes. These still required the learner to assimilate what was taught, but it was possible to do this at the most appropriate time for them, which might not be in a class room environment. It was a complex issue to cater for the different modes of learning of all students, such as preferences for visual, sensory or auditory assimilation of data, alongside the required formula and design process content. In terms of teaching, a generic teaching model and economies of scale were applied.

Most recently, constructivist theories of learning have evolved (Piaget 1970, Vygotsky 1962). These require the student to take an active role and responsibility for his/her learning within the context of making sense of his or her own world. These theories recognise that an individual cannot be programmed and that their way of being depends upon nature, nurture and, most importantly, the social context they live in. It is these facets of human life that dictate how learners construct and interpret meaning for themselves, via transactions with teachers, peers and their social and knowledge networks (Laurillard 2012). In constructivism, knowledge is not absolute or even static, but changes in the perceptions of the learner over time and depends upon the context they find themselves in at any given point in time. From this perspective, learners are the creators of their own knowledge and the teacher's role, then, is to facilitate access to knowledge sources and networks that meet both their needs and those of their programme of study (Biggs 2003). This is where online resources are particularly applicable, as they have the ability to provide a wide range of information sources and knowledge networks that the student can engage with, guided by the teacher, who is him/herself the hub of the knowledge network for his/her students (Bransford et al 2004, Wolf and Kolb 1984).

Goodhew (2010), in his book about teaching engineering refers to chartered engineers as being creative problem solvers and innovators. They need to be 'rational and pragmatic, interested in the practical steps necessary for a concept to become reality...want to solve problems...and have strategies...employing their knowledge in a flexible manner' (Engineering Benchmark Statement, QAA, 2006, cited in Goodhew, 2010, page 10). These abilities and skills do not come naturally to all engineers, so somehow they 
need to be taught. It seems that online resources have a role to play in facilitating this knowledge transfer, due to their facility for accessing a range of sources and explanations of theory in a format that is digestible to students with different interests and abilities (Creanor et al 2007).

\section{The Role of it in Civil Engineering Teaching}

Given the global social context of life that is facilitated by web and telecommunications today, it can be no surprise that the attitudes, behaviours, expectations and ways of learning of students today must be different from those of previous generations. No longer is the teacher the font of all knowledge and expertise - this is available freely via a range of online resources - but the teacher needs to be a guide to what the appropriate knowledge is, where to access it and how to interpret it (Case 2008). This means that the way engineering is taught must also be quite different in future.

\section{Data Overload}

The expansion of knowledge has been exponential and not only do graduates have to be engineers; they also have to think globally, be entrepreneurs, intrapreneurs and team players. This is in order to have the transferable skills required to compete in a global market (e.g. as in the Institution of Civil Engineers strategy (ICE, 2013) and other Engineering Council member Institutions) and means that, as teachers, we must learn to support and facilitate in ways that may seem quite alien to us (Farrell 2003).

Another issue is the underpinning learning that students have had before they come to study. This may differ wildly due to culture, language, types of school or college qualifications taken. Lack of prior access to IT services may also limit the students' ability to engage with all the web based services that are available to them.

\section{Using Online Resources in Teaching}

At the early stages of learning, it may be better to control access to external, uncontrolled data until the student is discerning enough to use it properly (Goodhew 2010). Internal Virtual Learning Environments (VLE) and other university fora can provide a wide range of learning resources. Excel spreadsheets and modelling software can facilitate the exploration of theory through practical examples/experiments that test the students understanding.

As the student develops and progresses and more complex concepts are studied, access to external online resources is useful to support guided learning (Fry et al 1999). These can be incorporated into lecture slides and introduced to the student as part of a wider world of learning that they can choose to access. These must be seen to be relevant to the discourse and their introduction needs to be timed to demonstrate the more global aspects and concerns that arise at a given point in the teaching. Links to regulatory guidance, or professional body resources or global environmental scenarios, maps and climate change charts for 
example, can broaden the impact of the face to face learning and allow the student to explore his/her own interests alongside the core material in a controlled and guided way.

\section{What Online Resources Can and Cannot Do}

Online services are a resource for learning and teaching, but are not a substitute for it. The student still has to assimilate the knowledge and the teacher still has to impart it, or guide the discovery of it in a digestible form. Online resources can, however, make it more fun to learn and show the relevance of the taught material to the real world the student will eventually have to work in (Bates et al, 2007). It can help students to keep up by accessing material in their own time and at the time during the day when they learn best, which is not necessarily in class.

\section{Methodology}

An online test each semester was instituted from 2009 for first year fluid mechanics and thermo-dynamics students in a 24 week taught module. The test comprises a series of mathematically oriented questions which require the use of theoretical equations to solve engineering problems. This format works well with calculations that have a specific answer and rounding can be accounted for by setting a range to the answer.

Similar examples are given in class and the students can refer to class notes (open book) when attempting the test, in their own time. The test is automatically assessed by the grade centre software. Feedback is instantly given on success in answering the questions correctly, and the correct answer is cited as feedback.

The students are given a dummy test to allow them to practise at answering questions, to help to overcome any lack of expertise in using the software. The dummy test is shorter than the actual test, but has a number of similar questions. Its main purpose is familiarisation with the software and test administration, before doing the actual test.

The actual assessed test then follows the same format as the dummy but with more questions, is one attempt, one hour and is open for three weeks to allow students to take it at a time to suit their workload. Two other assessments per semester, one a written piece of work and the other a formal are also taken in each semester. After the first, trial test, the students were canvassed for their acceptance of the test, though a student feedback survey. After a bedding in period, during which verbal feedback was gathered and used to improve the test, this survey was repeated, to test whether the outcomes and student views had changed. In year 5 of testing extra questions were added to the student survey about pre-existing experience of using IT software, including social media via mobile phone, word documents, Excel spreadsheets, access/databases, PowerPoint, websites and apps, other software. 
Findings

Marks in General

A general observation is that (Table 1), over the five years since its inception, most students pass these online, open book tests. If they do not, it is usually because they have not practised effectively with the dummy test, or press the submit button too early, or run out of time (noted from verbal student feedback). They appreciate, in the main, being able to do them at a time that suits them best. As we have a large percentage of part-time students, this flexibility of assessment is helpful to them. 2009-10 was the first, or pilot year for the test and the feedback from students was fed into the subsequent testing set up.

Table 1. Marks for On-line Tests from 2009-10 to 2012-13

\begin{tabular}{|c|c|c|c|c|c|c|c|}
\hline Year & $\mathbf{2 0 0 9 - 1 0}$ & \multicolumn{2}{|c|}{$\mathbf{2 0 1 0 - 1 1}$} & \multicolumn{2}{|c|}{$\mathbf{2 0 1 1 - 1 2}$} & \multicolumn{2}{|c|}{$\mathbf{2 0 1 2 - 1 3}$} \\
\hline Marks & Test 3 & Test 1 & Test 3 & Test 1 & Test 3 & Test 1 & Test 3 \\
\hline $0-20^{*}$ & 15 & 2 & 5 & 7 & 3 & 4 & 7 \\
\hline $21-40$ & 17 & 1 & 7 & 12 & 2 & 0 & 0 \\
\hline $41-60$ & 11 & 1 & 2 & 14 & 6 & 5 & 0 \\
\hline $61-80$ & 11 & 2 & 5 & 18 & 14 & 10 & 1 \\
\hline $81-100$ & 9 & 29 & 16 & 5 & 31 & 15 & 26 \\
\hline Total & 63 & 35 & 35 & 56 & 56 & 34 & 34 \\
\hline
\end{tabular}

There are always some students who have difficulty executing these types of test correctly, but most get a better pass rate for these tests than for more formal styles of testing (Table 1, compared with Tables, 2, 3, 4 and 5). Over the 24 weeks of module teaching this balances the marks overall, testing not just memory, but ability to use theory in different ways and apply it under different test conditions, as well as identifying where numeracy and writing skills require work.

Table 2. Marks for other Tests in 2009-10

\begin{tabular}{|c|c|c|c|c|c|}
\hline Year 2009-10 & Test 1 & Test 2 & Test 4 & Course $1^{*}$ & Course 2** \\
\hline $0-20$ & 16 & 11 & 17 & 15 & 16 \\
\hline $21-40$ & 10 & 9 & 12 & 23 & 2 \\
\hline $41-60$ & 15 & 14 & 17 & 18 & 31 \\
\hline $61-80$ & 13 & 13 & 11 & 7 & 14 \\
\hline $81-100$ & 9 & 16 & 6 & 0 & 0 \\
\hline Total & 63 & 63 & 63 & 63 & 63 \\
\hline
\end{tabular}

*Course 1 is a written coursework on fluid mechanics in the form of interpreting laboratory data. ** Course 2 is a written essay on thermodynamics

Another interesting finding is that students fare worse in written coursework than in numerical class tests, possibly due to a focus on science/mathematics rather than verbal/writing skills during pre-learning. Workload is spread out 
across the semester and cognisance is taken of work being issued on other modules, via consultation with colleagues and the students themselves.

Table 3. Marks for other Tests in 2010-11

\begin{tabular}{|c|c|c|c|c|}
\hline Year 2010-11 & Test 2 & Test 4 & Course 1 & Course 2 \\
\hline $0-20$ & 3 & 6 & 1 & 4 \\
\hline $21-40$ & 5 & 9 & 7 & 7 \\
\hline $41-60$ & 6 & 9 & 20 & 17 \\
\hline $61-80$ & 9 & 6 & 5 & 5 \\
\hline $81-100$ & 10 & 3 & 0 & 0 \\
\hline Total & 33 & 33 & 33 & 33 \\
\hline
\end{tabular}

It is also interesting to note the variation in marks with cohort, as every year presents different data. Some years, e.g. 2012-13, have a cohort with poorer writing/analytical skills than other years, whereas numerical testing reveals greater numeracy. In other years, this trend is reversed and in some years, everyone seems to hone to the middle road in both areas of skill.

Table 4. Marks for other Tests in 2011-12

\begin{tabular}{|c|c|c|c|c|}
\hline Year 2011-12 & Test 2 & Test 4 & Course 1 & Course 2 \\
\hline $0-20$ & 6 & 13 & 2 & 5 \\
\hline $21-40$ & 12 & 13 & 3 & 8 \\
\hline $41-60$ & 13 & 12 & 23 & 35 \\
\hline $61-80$ & 18 & 9 & 22 & 6 \\
\hline $81-100$ & 6 & 8 & 5 & 1 \\
\hline Total & 55 & 55 & 55 & 55 \\
\hline
\end{tabular}

Table 5. Marks for other Tests in 2012-13

\begin{tabular}{|c|c|c|c|c|}
\hline Year 2012-13 & Test 2 & Test 4 & Course 1 & Course 2 \\
\hline $0-20$ & 2 & 3 & 2 & 2 \\
\hline $21-40$ & 3 & 5 & 9 & 10 \\
\hline $41-60$ & 4 & 12 & 19 & 18 \\
\hline $61-80$ & 12 & 10 & 1 & 1 \\
\hline $81-100$ & 10 & 1 & 0 & 0 \\
\hline Total & 31 & 31 & 31 & 31 \\
\hline
\end{tabular}

This would seem to indicate that assessment is not an exact science, in that all people respond differently to different ways of being tested and their variety in any year cannot be predicted. The best we can do then, as assessors, is to:

- Listen to student feedback

- Take a balanced view of what they indicate may be helpful to their performance

- Use established and recognised assessment designs

- Monitor a range of cohorts over several years to ensure that fairness and learning outcomes are achieved. 


\section{Online Testing}

The modus operandi for taking the tests and strong encouragement to practise with the dummy test first are highlighted several times in the run up to the testing period. The online testing has run for five years now and pass rates for it have generally been high.

Table 6a. 2009-10 Student Feedback Survey

\begin{tabular}{|c|c|c|c|c|c|c|c|c|}
\hline Question & Yes & No & $\begin{array}{l}\text { Don't } \\
\text { know }\end{array}$ & \multicolumn{5}{|c|}{ Comments } \\
\hline $\begin{array}{l}\text { 1. Did you } \\
\text { find the } \\
\text { test easy to } \\
\text { navigate? }\end{array}$ & 26 & 4 & & & & & & \\
\hline $\begin{array}{l}\text { 2. What } \\
\text { would } \\
\text { make it } \\
\text { easier to } \\
\text { navigate? } \\
\text { Please } \\
\text { specify }\end{array}$ & & & & $\begin{array}{c}\text { If Qs } \\
\text { continued } \\
\text { on each } \\
\text { page (1) }\end{array}$ & $\begin{array}{l}\text { List of Qs } \\
\text { on first } \\
\text { page to } \\
\text { allow } \\
\text { selection of } \\
\text { which to } \\
\text { attempt } \\
\text { first to } \\
\text { prevent } \\
\text { rushing/loss } \\
\text { of marks at } \\
\text { end (3) }\end{array}$ & $\begin{array}{c}\text { Repeating } \\
\text { Q every } \\
\text { page (5) }\end{array}$ & $\begin{array}{l}\text { Being } \\
\text { able to } \\
\text { move } \\
\text { between } \\
\text { Qs (1) }\end{array}$ & $\begin{array}{c}\text { Could } \\
\text { not sit } \\
\text { test as } \\
\text { thrown } \\
\text { out } \\
\text { and } \\
\text { could } \\
\text { not re- } \\
\text { enter } \\
\text { (1) }\end{array}$ \\
\hline $\begin{array}{l}\text { 3. Did you } \\
\text { get enough } \\
\text { feedback } \\
\text { on your } \\
\text { answer? }\end{array}$ & 5 & 24 & & & & & & \\
\hline \multicolumn{9}{|c|}{ 4. If you answered no to Q3 above, what would you like to have? } \\
\hline $\begin{array}{l}\text { a. More } \\
\text { detail of } \\
\text { solution }\end{array}$ & 18 & & & & & & & \\
\hline $\begin{array}{l}\text { b. Link to } \\
\text { a solution }\end{array}$ & 17 & & & & & & & \\
\hline c. Other & 1 & & & $\begin{array}{c}\text { Left } \\
\text { answer } \\
\text { blank and } \\
\text { was shut } \\
\text { out of } \\
\text { test - no } \\
\text { feedback } \\
\text { (1) }\end{array}$ & $\begin{array}{c}\text { More Qs } \\
\text { with } \\
\text { sections } \\
\text { with fewer } \\
\text { marks. One } \\
\text { Q was } 25 \\
\text { marks and } \\
\text { if wrong } \\
\text { was a large } \\
\text { loss of } \\
\text { marks (3) }\end{array}$ & $\begin{array}{l}\text { Credit for } \\
\text { working } \\
\text { (1) }\end{array}$ & $\begin{array}{c}\text { Units } \\
\text { can } \\
\text { affect if } \\
\text { answer } \\
\text { right or } \\
\text { wrong - } \\
\text { units } \\
\text { should } \\
\text { be } \\
\text { specified } \\
\text { (3) }\end{array}$ & \\
\hline $\begin{array}{l}\text { 5. Do you } \\
\text { like doing } \\
\text { class tests } \\
\text { this way? }\end{array}$ & 14 & 14 & 2 & $\begin{array}{l}\text { Tried to } \\
\text { log in but } \\
\text { could not }\end{array}$ & $\begin{array}{c}\text { No - easier } \\
\text { when a test } \\
\text { is on paper } \\
\text { to refer } \\
\text { back to Q }\end{array}$ & $\begin{array}{c}\text { Yes - } \\
\text { enjoyed } \\
\text { doing it } \\
\text { in own } \\
\text { time (1) }\end{array}$ & $\begin{array}{c}\text { Open } \\
\text { book } \\
\operatorname{good}(4)\end{array}$ & \\
\hline
\end{tabular}


The first survey about the online test for first years showed (Table 6a) that, although the majority of respondents (87\%) found the test easy to navigate, $83 \%$ did not feel they had sufficient feedback, and only $47 \%$ actually liked doing tests in this way.

Table 6b. 2012-13 Student Feedback Survey

\begin{tabular}{|c|c|c|c|c|c|c|}
\hline Question & Yes & No & Don't know & \multicolumn{3}{|c|}{ Comments } \\
\hline $\begin{array}{c}\text { 1. Did } \\
\text { you find } \\
\text { the test } \\
\text { easy to } \\
\text { navigate? }\end{array}$ & 19 & 0 & & & & \\
\hline $\begin{array}{l}\text { 2. What } \\
\text { would } \\
\text { make it } \\
\text { easier to } \\
\text { navigate? } \\
\text { Please } \\
\text { specify }\end{array}$ & & & 1 & $\begin{array}{c}\text { better layout } \\
\text { of questions } \\
\text { (4) }\end{array}$ & $\begin{array}{c}\text { Individual } \\
\text { question } \\
\text { pages (1) }\end{array}$ & $\begin{array}{l}\text { Could not } \\
\text { sit test as } \\
\text { thrown } \\
\text { out and } \\
\text { could not } \\
\text { reenter } \\
\text { (3) }\end{array}$ \\
\hline $\begin{array}{l}\text { 3. Did } \\
\text { you get } \\
\text { enough } \\
\text { feedback } \\
\text { on your } \\
\text { answer? }\end{array}$ & 5 & 15 & & & & \\
\hline
\end{tabular}

4. If you answered no to Q3 above, what would you like to have?




These responses were taken into account and the answers to the test question are now incorporated into the module documentation. Some students failed to $\log$ in/out correctly, despite having tried the dummy test, which is accessed and submitted in the same way. Some students asked for all questions to be open at the same time so they could choose which to answer first, as they would in a normal test.

These inputs were fed into the following year's test format, which had units specified, answer ranges and all questions available at once, to enable the students to choose which to do first. Any student who fails to get a pass mark is offered a paper version of the test.

In the second survey four years later (Table 6b), again the majority of respondents $(95 \%)$ found navigation easy, but said they would prefer individual question pages - the opposite of the original cohort - or better layout of questions. Again, some could not sit the test, despite having tried the dummy test and some were locked out, 'not realising' it was a one shot test.

\section{Student Engagement in the Survey}

These feedbacks are interesting in that, despite continual improvement in the test administration over the years, student perceptions do not really seem to reflect that improvement. In fact, at the last survey, a greater percentage of respondents did not like doing tests in this way (57\% in $2012-13$ vs $47 \%$ in 2009-10).

\section{Pass Rates and Progression}

Pass rate and progression analysis is complicated by students who withdraw and/or resit more than once. Students are allowed up to four attempts at a module overall and so in some cases will carry one forward to the following session. This data (Table 7) attempts to smooth out these issues, by removing those students from the analysis.

Table 7. Smoothed Out Module Pass Rates since On-line testing has been in Place

\begin{tabular}{|c|c|c|c|c|c|c|}
\hline Session & $\begin{array}{c}\text { Students } \\
\text { Registered }\end{array}$ & $\begin{array}{c}\text { Passed } \\
\text { 1st Diet }\end{array}$ & $\begin{array}{c}\text { Passed } \\
\text { 2nd Diet }\end{array}$ & $\begin{array}{c}\text { Passed } \\
\text { Total }\end{array}$ & $\begin{array}{c}\text { Mean } \\
\text { mark }\end{array}$ & $\begin{array}{c}\text { \% Total } \\
\text { Passed }\end{array}$ \\
\hline $2012-13$ & 31 & 27 & & 27 & $63 \%$ & 86 \\
\hline $2011-12$ & 55 & 46 & 2 & 48 & $54 \%$ & 87 \\
\hline $2010-11$ & 35 & 28 & 0 & 28 & $40 \%$ & 80 \\
\hline $2009-10$ & 63 & 44 & 4 & 48 & $43 \%$ & 76 \\
\hline
\end{tabular}

Student numbers vary and this is partly due to changes to other programmes, which at various times engage with civil engineering during their first year of study, and to the economic climate, which reduces part time, company funded student numbers. Part-timers achieve higher overall module marks than do full- 
timers (Table 8), probably because they are company funded and their employer expectations are high, as is their personal motivation to do well.

Table 8. Part-time vs Full-time overall First Diet Percentage at Level (no data for 2009-10)

\begin{tabular}{|c|c|c|c|c|c|c|}
\hline \multirow{2}{*}{ Level } & \multicolumn{2}{|c|}{ 2010-2011 } & \multicolumn{2}{c|}{ 2011-2012 } & \multicolumn{2}{c|}{ 2012-2013 } \\
\cline { 2 - 7 } & PT & FT & PT & FT & PT & FT \\
\hline $0-20$ & & 7 & & 2 & & \\
\hline $21-40$ & 25 & 10 & 14 & 16 & & \\
\hline $41-60$ & & 40 & 57 & 47 & 67 & 26 \\
\hline $61-80$ & 75 & 43 & 29 & 35 & 33 & 74 \\
\hline $81-100$ & & & & & & \\
\hline
\end{tabular}

Also, they generally exhibit more maturity in their work organisation and in the first year of study, this can cause a significant difference in attitude and behaviour between full and part timers and in quality of work and pass rates.

Pre-existing IT Usage

In the fifth year of on-line testing additional questions were added to the student survey to establish student pre-existing skill with using a range of software before joining the programme. It was found that $80 \%$ of respondents have experience in using many types of applications; social media via mobile phone, word documents, Excel spreadsheets, and PowerPoint, 70\% had used Access/databases, websites and apps, and $40 \%$ have experience in using other software such as CAD, Autodesk and Matlab. My previous experience with students was that some had very little knowledge of software applications, except in a social context, but this is clearly changing.

\section{Conclusions}

\section{Findings Conclude that}

- Our engineering students are more numerical than verbal in their skill sets in first year and so fare worse in written coursework than in numerical tests at this level of study

- Some first year students have not had the benefit of regular or wide access to IT facilities during pre-learning, which inhibits their engagement with, and liking for on-line testing until they are more confident with using computers and a range of software and university web based services. However, the majority have a wide range of experience with generic software and some are adept with technical software such as CAD, Autodesk and Matlab

- Over the five years of this investigation, it was noted that different cohorts of students display differences in these skill sets year by year, which has implications for changes and 
enhancements to assessments over time. Assessment is therefore not an exact science, in that different students respond differently to different ways of being tested and their variety in any year cannot be predicted

- Lecturers need therefore to listen to student feedback and take a balanced view of what students indicate may be helpful to their performance. Established and recognised assessment designs and monitoring of cohorts across several years are needed to ensure that assessments are fair and sustainable

- Students like open book testing and want detailed solutions to be provided as feedback soon after testing so that they can get the most out of the learning experience

- Despite continual adjustments and improvements to the on-line test over the four years, based on student feedback, improvements are not reflected in student perceptions of the test

\section{Positives of On-line Testing}

- Most students found the test easy to navigate, especially having practised with the dummy test beforehand

- The on-line test provides an alternate type of assessment for students who do not perform so well in more formal examinations or written courseworks and allows them to increase their average pass rates for the module

- The online test particularly suits part timers (noted from verbal feedback), who do much of their study in their own time and this has tended to enhance their marks overall. In general the students like being able to do the test 'in their own time'

- The test forces students to consult their lecture notes early in the semester in order to complete the test, using similar worked examples from class. This should support learning outcomes related to theory and design of engineering solutions to problems set

- More students tend to pass these online tests than more formal exam style closed book tests, despite their lack of enjoyment in executing them

- My workload, instead of being focused on marking, has been used to explain how the online testing works and to facilitate discussions in class during the dummy test practice period.

Negatives of On-line Testing

- Some students find the time constraints stressful, even in an open book test, when they have had a practice test beforehand to help them

- Despite expectations of working with 'digital natives', many students do not like online testing due to their lack of experience 
with this type of software and despite having a dummy test to practise on.

- Most students would like a link to, or a more detailed solution to be provided as feedback. The software has limited feedback capability for this type of questioning, but answers are provided for students in their web based module link

- This mode of assessment does not seem to have impact upon the reluctance of many students to engage with the lecture notes/course material and did not seem to increase their familiarity with the module topics in many cases.

\section{Ideas for Future Development of the On-line Test}

- I need to explain with greater clarity the purpose and learning objectives of the online test and to introduce the students to the dummy test on screen during class to overcome their reluctance to engage fully with this type of assessment

- I need to ensure a balanced question structure in terms of mark allocation so that students feel the marking is fair, particularly if they ran out of time on a more heavily weighted question

- It is essential to give written feedback, as answers to questions posed, in order that students can see where they went wrong exactly

- In addition, more investigation is required into why a proportion of students say they do not like this type of test even if they do well in it.

In summary, using online testing does not suit everyone and requires up front detailed explanation of how the test works and practice with the software before testing can begin. Equally, balancing questions in the test is important to reducing the student concerns about large questions potentially skewing the final mark. To get real student engagement in the online test process, students need to see the benefits of it for them, in their mode of learning. Good students and parttimers gain benefit from this type of testing, which they can do at a time that suits them best. On balance, online testing can be seen to be an effective method of assessment, from this limited study, but it needs to be set up and administered in a clear and consistent fashion.

\section{References}

Atkinson, R. C., and Shiffrin, R. M. 1968. Spence, K. W. and Spence, J. T., ed. The psychology of learning and motivation (2 ed.). New York: Academic Press. pp. 89-125.

Baddeley, A. D., and Hitch, G. J. L. 1974. Bower, G. A., ed. The psychology of learning and motivation: advances in research and theory (8 ed.). New York: Academic Press. pp. 47-89. 
Bates, J., Hardy, J., Hill, J. and McKain, D. 2007-8. How Design of Online Learning materials can accommodate the heterogeneity of student abilities, aptitudes and aspirations. Learning and Teaching in Higher Education, Issue 2, pp3-25.

Biggs, J. 2003. Teaching for quality learning at university. $2^{\text {nd }}$ edition. OU Press.

Bransford, J. D., Brown, A. L. and Cocking, R. R. 2004. How Students Learn: History, Mathematics, and Science in the Classroom. National Research Council of the National Academes, USA.

Case, J. 2008. Education Theories on Learning. An informal guide for the engineering education scholar. Engineering Subject Centre Guide. The Higher Education Academy. ISBN-978-904804-91-8(print) - 5 (online).

Creanor, L., Trinder, K., Gowan, D. and Howells, C. 2007-8. Lifelong learning and technology: views from the learners. Learning and Teaching in Higher Education, Issue 2, pp 26-41.

Farrell, M. 2003. Collaborative Circles: Friendship, Dynamic and Creative Work. University of Chicago Press.

Fry, H., Ketteridge, S., \& Marshall, S. A handbook for teaching and learning in higher education - enhancing academic practice, 1999, Routledge Press

Goodhew, P. 2010. Teaching Engineering. All you need to know about engineering education but were too afraid to ask. UK Centre for Materials Solutions. The Higher Education Academy. ISBN-978-1-907207-22-8.

Harasim, L. 2012. Learning theory and online technology, ISBN: 978-0-415999-7-6. Online resource.

ICE, 2013. http://www.ice.org.uk/qualification-careers/Graduate-careers-section/Ski lls---development, accessed 04/09/2013

Laurillard, D. 2012. Teaching as a design Science, Routledge.

Piaget, J. 1970. Science of education and the psychology of the child. New York: Orion Press.

Skinner, B. F. 1948. 'Superstition' in the pigeon. Journal of Experimental Psychology, 38, 168-172.

Thorndike, E. L. 1905. The elements of psychology. New York: A. G. Seiler.

Vygotsky, D. 1962. Thought and language. Cambridge, MA: MIT Press.

Wolf, D. M. and Kolb, I. 1984. Career development, personal growth and experiential learning, in Organisational Psychology: Readings on human behaviour. $4^{\text {th }}$ edition. (ed Kolb, D., Rubin, I. and MacIntyre, J.), Prentice-Hall, Englewood Cliffs, New Jersey. 
